УДК 51-7.+535.3

P.P. TROKHIMCHUCK

Lesya Ukrayinka Volyn' National University

\title{
MODELLING OF THE ELIONIC-INDUCED SPUTTERING (SUBLIMATION) OF MATTER
}

\begin{abstract}
The problem of modeling the elionic-induced sputtering (sublimation) of matter is represented. It is customary to call elionic technologies the technologies for processing matter with particle beams (ions, neutrons, electrons and photons). Short review of corresponding experimental data of represented. The ways of search the creation of universal theory for the explanation the proper experimental data are discussed. Comparative analysis of thermodynamical theory, physical-chemical models and photo induced theory of sublimation is described. We show that problem of laser-induced sublimation may be represented as surface sputtering of matter. Therefore the problems of ion-induced and electron induced sputtering of matter are analysed too. From physical-chemical point of point of view the processes of sublimation and sputtering have of the same nature. Main difference between laser-induced and particle-induced sputtering (sublimation) is the nature of interaction charge particles and photons with matter. In both cases we have critical value of fluence the corresponding particles. So, for ion implantation surface sputtering is beginning from fluence $3 \cdot 10^{18} \mathrm{~cm}^{-3}$. For electrons this value on 2-3 orders of magnitude is greater. Neutron irradiation has a high penetrating ability and material sputtering processes are typical for nuclear and thermonuclear reactors. For laser radiation, the chain process of saturation of the excitation of the corresponding chemical bonds plays an important role. The methods of radiation physics of status solid, Relaxed Optics and irreversible thermodynamics were chosen for modeling. Ion sputtering occurs when irradiated with large doses of ions. In this case, the coefficient of sputtering of the irradiated material is of great importance. Based on this, a physicochemical model is presented, which allows describing the processes of ion sputtering of one and diatomic materials. To simulate laser-induced sublimation, a cascade model of excitation of the corresponding chemical bonds in the excitation saturation mode was used. A comparative analysis with the thermodynamic theory of sublimation is carried out. It is shown that the thermodynamic energy threshold of sublimation is 0.4 values of the Zeitz energy. Estimated calculations for silicon, germanium and steel are presented.
\end{abstract}

Key words: laser-induced sublimation, Relaxed Optics, modeling, chain processes, sputtering, elionic technologies, ion implantation, accelerators.

П.П. ТРОХИМЧУК

Волинський національний університет імені Лесі Українки

\section{МОДЕЛЮВАННЯ ЕЛІОННО-ІНДУКОВАНОГО РОЗПИЛЕННЯ (СУБЛІМАЦІї) РЕЧОВИНИ}

\begin{abstract}
Представлена задача моделювання еліонно-індукованого розпилення (сублімачії) речовини. Еліонними технологіями прийнято називати технології обробки речовини пучками частинок (іони, нейтрони, електрони i фотони). Наведено короткий огляд відповідних експериментальних даних. Обговорено иляхи пошуку створення універсальної теорії для пояснення ичи експериментальних даних. Описано порівняльний аналіз термодинамічної теорії, фізико-хімічних моделей та фотоіндукованої теорії сублімації. Показано, шзо проблему лазерно-індукованої сублімації можна представити як поверхневе розпилення речовини. Тому також аналізуються проблеми іонного та електронного розпилення речовини. 3 фізико-хімічної точки зору прочеси сублімації та рорзпилення мають однакову природу. Основна різниця між індукованою лазерно-індукованим та частинково-індукованим розпиленням (сублімацією) полягає в характері взаємодії заряджених масивних частинок $i$ фотонів 3 речовиною. В обох випадках ми маємо критичне значення потоку відповідних частинок. Так, для іонної імплантації атомізація поверхні починається з флюенсу $3 \cdot 10^{18} \mathrm{~cm}^{-3}$. Для електронів цзе значення на 2-3 порядки більше. Нейтронне опромінення має велику проникаючу здатність $i$ процеси розпилення матеріалу характерні для ядерних і термоядерних реакторів. Для лазерного випромінювання велику роль має ланцюговий процес насичення збудження відповідних хімічних зв'язків. Для моделювання були обрані методи радіаційної фізики твердого тіла, релаксаційної оптики та незворотної термодинаміки. Іонне розпилення відбувається при опроміненні великими дозами іонів. Велике значення при иьому має коефіиієнт розпилення опроміненого матеріалу. Виходячи з иъього приведена фізико-хімічна модель, яка дозволяє описати процеси іонного розпилення одне $і$ двоатомних матеріалів. Для моделювання лазерноіндукованої сублімації була використана каскадна модель збудження відповідних хімічних зв'язків в режимі насичення збудження. Проведено порівняльний аналіз з термодинамічною теорією сублімації.
\end{abstract}


Показано, що термодинамічний енергетичний поріг сублімації становить 0,4 значення від енергії Зейтия. Наведено оціночні розрахунки для кремнію, германію та стали.

Ключові слова: лазерно-індукована сублімація, релаксачійна оптика, моделювання, ланцюгові прочеси, розпилення, еліонні технологїі, іонна імплантація, прискорювачі.

П.П. ТРОХИМЧУК

Волынский национальный университет имени Леси Украинки

\title{
МОДЕЛИРОВАНИЕ ЭЛИОННО-ИНДУЦИРОВАННОГО РАСПЫЛЕНИЯ (СУБЛИМАЦИИ) ВЕЩЕСТВА
}

\begin{abstract}
Представлена задача моделирования элионно-индуцированного распыления (сублимации) вещества. Элионными технологиями принято называть технологии обработки вещества пучками частиц (ионы, нейтроны, электроны и фотоны). Приведен краткий обзор соответствуюших экспериментальных данных. Обсуждены пути поиска создания универсальной теории для объяснения этих экспериментальных данных. Описан сравнительный анализ термодинамической теории, физикохимических моделей и фотоиндуцированной теории сублимации. Показано, что проблему лазерноиндуцированной сублимации можно представить как поверхностное распыления вещества. Поэтому также анализируются проблемы ионного и электронного распыления вещества. С физико-химической точки зрения процессы сублимации и распыления имеют одинаковую природу. Основная разница между лазерно-индуцированным и частище-индуцированным распылением (сублимацией) заключается $в$ характере взаимодействия заряженных массивных частии и фотонов с веществом. В обоих случаях мыл имеем критическое значение потока соответствующих частиц. Так, для ионной имплантации атомизация поверхности начинается с потока ионов $3 \cdot 10^{18} \mathrm{~cm}^{-3}$. Для электронов это значение на 2-3 порядка больше. Нейтронное облучение имеет большую проникаюшую способность и процессы распыления материала характерны для ядерных и термоядерных реакторов. Для лазерного излучения большую роль имеет ичепной процесс насыщения возбуждения соответствующих химических связей. Для моделирования были выбраны методы радиационной физики твердого тела, релаксационной оптики и необратимой термодинамики. Ионное распыление происходит при облучении больиими дозами ионов. Большое значение при этом имеет коэффициент распыления облучаемого материала. Исходя из этого, приведена физико-химическая модель, которая позволяет описать проиессы ионного распыления одно и двухатомных материалов. Для моделирования лазерно-индуцируемой сублимации была использована каскадная модель возбуждения соответствуюших химических связей в режиме насыщения возбуждения. Проведен сравнительный анализ с термодинамической теорией сублимации. Показано, что термодинамический энергетический порог сублимации составляет 0,4 значення от енергии Зейтца. Приведены оченочные расчеты для кремния, германия и стали.

Ключевые слова: лазерно-оптический пробой, релаксационная оптика, моделирование, изепные процессы, черенковское излучение.
\end{abstract}

\section{Introduction}

Problems of the observation the elionic-induced sublimation and sputtering of matter is one of the central questions of modern elionic technology [1-9]. Concept elionic are including all possible types of particle irradiation, including photons [4]. This problem is connected with problem of ion- and electron-induced sputtering of irradiated surface with help accelerators of proper particles, including photons. Particle-induced processes $[1,2,4,6-$ 8] are "hard" processes; laser-induced sublimation (sputtering) is more soft process $[3,7,9]$. For the case of laser irradiation we have two scenarios of evaporation [3]. First is connected with melting of irradiated matter (evaporation from melting liquid phase) and sublimation (evaporation from solid state).

We present this problem from one point of view for all types of interaction from photon to ions. It is the first attempt of observation this problem in main detail in whole.

Main methods of modeling are physical chemical. All these processes have threshold nature. For ion and electron irradiation it depends from parameters of irradiation and type of irradiated matter.

For ion implantation we select macroscopic quantities: total sputtering ratio and selective sputtering coefficient $[4,6,7]$. This simple model allows explaining the main 
peculiarities of ion-induced sputtering of two and more numbers component systems. So, for ion implantation the threshold of sputtering of irradiated matter is $\sim 3 \cdot 10^{18} \mathrm{~cm}^{-2}[1,2,4,6-8]$. For electron irradiation this value has more on two order magnitude $[2,4,7]$.

Laser-induced processes have more soft nature [3,9]. Therefore, we must use the methods of modeling, which are allow to explain the possible chains intermediate phase transformations $[3,9]$. In this case we must use the cascade model of excitation of proper chemical bonds in the regime of saturation of excitation [3]. Roughly speaking, the laserinduced surface sputtering of irradiated matter without melting must be realized for the regime of irradiation, which is equal of sum the chemical bonds of surface atoms. As rule, this value is equal the half of Seitz energy (sum of all nearest chemical bonds of corresponding atoms in crystal lattice) [4]. In order of magnitude, this value corresponds to the sublimation energy of the irradiated material. In this case, we must select regimes of irradiation, which generating cascade "quantum" short-range actions, because the transition to long-range action may be cause of melting the irradiated matter.

The pure laser sublimation (sputtering) method is more preferable for obtaining the micro-hole drilling of stainless steel using short laser pulses [9], because it does not leave molten droplets on the irradiated surface, in addition, the holes themselves have a more even border.

In whole methods of elionic-induced sputtering may be used for the cleaning the surfaces of materials and their corresponding profiles, while laser methods can be used for samples with a significantly smaller size.

\section{Experimental data}

As the radiation dose of the target increases, if it is a single crystal, it can turn into a polycrystalline, amorphous state and collapse. In Fig. 1 shows the temperature dependence of the critical zone required for amorphization of the monocrystalline $S i$ by different ions. Ion sputtering starts at implantation doses $\sim 10^{18} \mathrm{~cm}^{-2}[4]$.

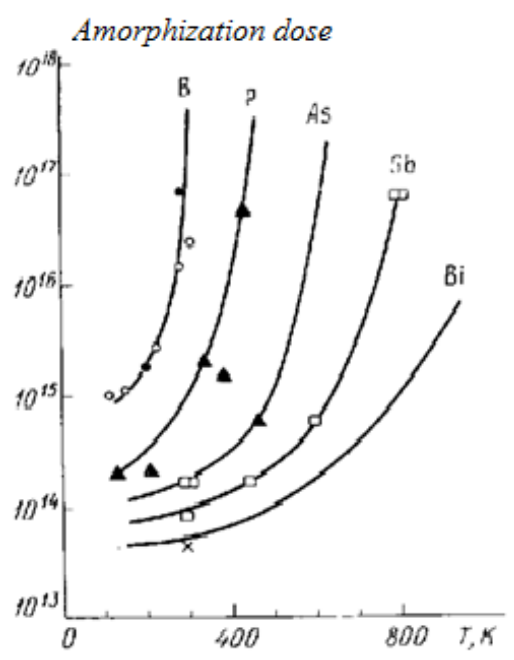

Fig. 1. Temperature dependence of the critical zone required for amorphization [4]

Dependence of sputtering coefficient with irradiation of potassium iodide without impurity and with an impurity of thallium is shown in Fig. 2 [7]. 


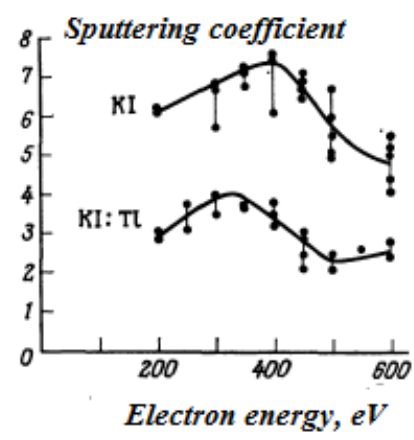

Fig. 2. Sputtering ratio $K I$ and $K I: T l$ by electrons at temperature $22{ }^{\circ} \mathrm{C}$ [7]. Impurity $T l$ acts as a trap for excitons andtherefore reduces the sputtering coefficient

Neutron irradiation has a high penetrating power, therefore, it leads to volume blistering and hydrogenation of the irradiated material, while ion sputtering of the irradiated material can naturally occur $[4,7]$.

The laser-induced evaporation (sputtering) may be realized with two channels: evaporation from a melt (ablation) and evaporation from a solid state (sublimation) [3, 9].

The main peculiarities of processes laser-induced evaporation may be explained on the laser-induced drilling. Creation of micro- holes with given parameters simplifies application of new generation of microelectronic components, microsensors, filters, surgical instruments etc. Therefore, micro-hole drilling in a wide range of materials, such as steel, copper, aluminum, etc., has received much attention [9].

The demands for high precise micro-holes are increasing with the increasing of application range, therefore traditional mechanical drilling is slightly applicable. On the other hand, laser drillingusing continuous-wave lasers is accompanied with the formation of melting layer and due to its uncontrolled redeposition - recast layer. The best way of overcoming main laser drilling disadvantages is laser pulse shortening, so that only material ablation by nonlinear absorption takes place [9]. Such material ablation could be achieved by using of picosecond or even femtosecond laser sources because ablation of pulsed laser radiation depends on the length of the respective pulse. Different pulse lengths have different etching mechanisms during removal of the material, and the shape of the material surface will be different after the removal process.

Although studies on micro-hole drilling by short pulsed lasers has received much attention, drilling of high precise micro-holes with minimal or no thermal damage still remains a major challenge [9].

In work [9] micro-hole drilling was processed using TRUMPF TruMicro 5000 picosecond laser. The wavelength of the laser was $515 \mathrm{~nm}$ with a pulse width of $10 \mathrm{ps}$ at 400 $\mathrm{kHz}$ pulse repetition frequency. The power density was $5.72 \cdot 10^{5} \mathrm{~W} \cdot \mathrm{cm}^{-2}$, and equivalence laser fluence was $1.43 \mathrm{~J} \cdot \mathrm{cm}^{-2}$. Micro-holes were received in steel SAE-304 (Fig. 3) [9].
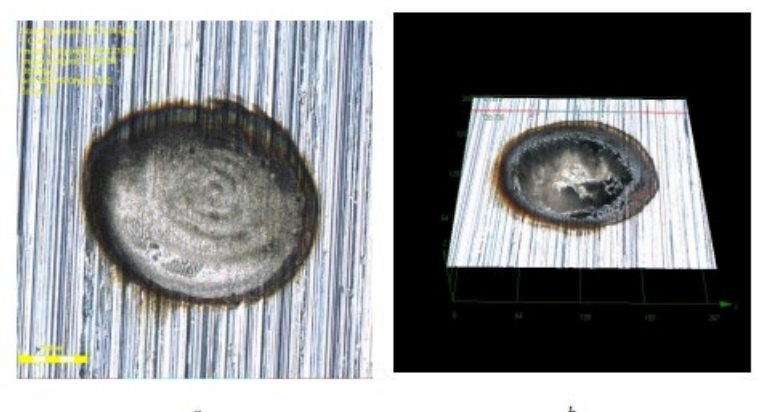

Fig. 3. Micro-holes drilled in stainless steel using picosecond laser: a - 30 shots, 2D view; b -190 shots, 3D - view [9] 

$4[9]$.

Line profiles of drilled micro-holes fordifferent amount of shots is represented on Fig.

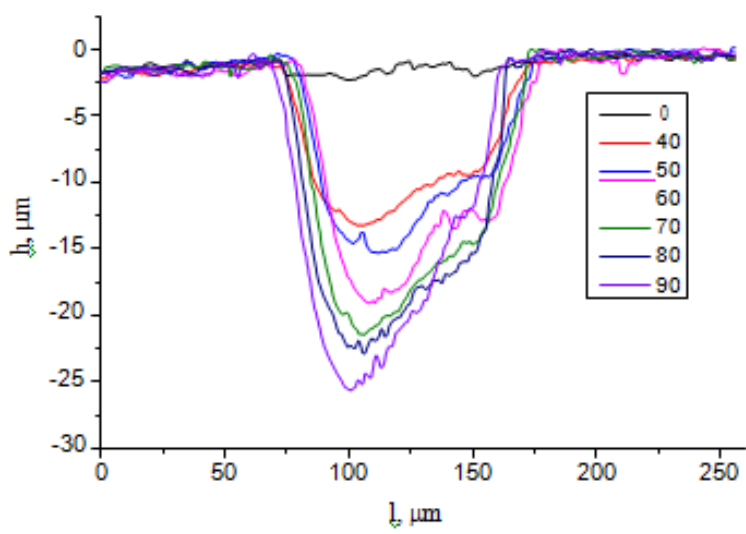

Fig. 4. Line profiles of drilled micro-holes fordifferent amount of shots [9]

Depth of the hole drilled using picosecond laser for different number of pulses was researched too (Fig. 5) [9].

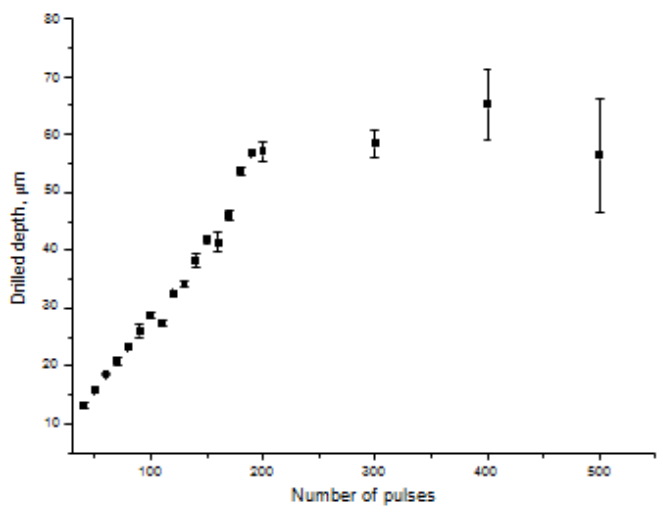

Fig. 5. Depth of the hole drilled using picosecond laser for different number of pulses [9]

As seen from Fig. 5 the dependence of the depth of holes tends to saturate. This is obviously due to the increase in light reflection compared to previous pulses.

In order to avoid dross (Fig. 3), it is advisable to choose the modes of laser irradiation such that the main processes are sublimation of the irradiated material. This mode is easy to choose, since the binding energy of near-surface atoms is 1.2 - 2 times less than that of bulk atoms, while we will have laser-induced sputtering with a solid rather than a liquid phase [9].

The edges of the holes will be smoother and by adjusting the irradiation time, we can get holes in a wider range of sizes. For these purposes, longer irradiation regimes can be used. Increasing the angle of incidence relative to the surface normal decreases the penetration depth of the incident particles into the material. A cascade of collisions occurs closer to the surface, its atoms receive a large share of the energy. The direction of the velocity imparted to the displaced atoms is more favorable for sputtering. However, at too large angles of incidence, the probability of reflection of the incident particle by the electric field on the surface increases without significant energy transfer to the target atoms.

\section{Modeling and discussions}


The problem of particle sputtering may be connected with thermodynamic concept of sublimation but although it also has significant differences due to the processes of interaction of specific particles with the environment $[4,7,9,10]$.

Sublimation is the transition of a substance directly from the solid to the gas state, without passing through the liquid state [10]. Sublimation is an endothermic process that occurs at temperatures and pressures below a substance's triple point in its phase diagram, which corresponds to the lowest pressure at which the substance can exist as a liquid. The reverse process of sublimation is deposition or desublimation, in which a substance passes directly from a gas to a solid phase. Sublimation has also been used as a generic term to describe a solid-to-gas transition (sublimation) followed by a gas-to-solid transition (deposition). While vaporization from liquid to gas occurs as evaporation from the surface if it occurs below the boiling point of the liquid, and as boiling with formation of bubbles in the interior of the liquid if it occurs at the boiling point, there is no such distinction for the solid-to-gas transition which always occurs as sublimation from the surface. Phase diagram of this processes is represented on Fig. 6 [10].

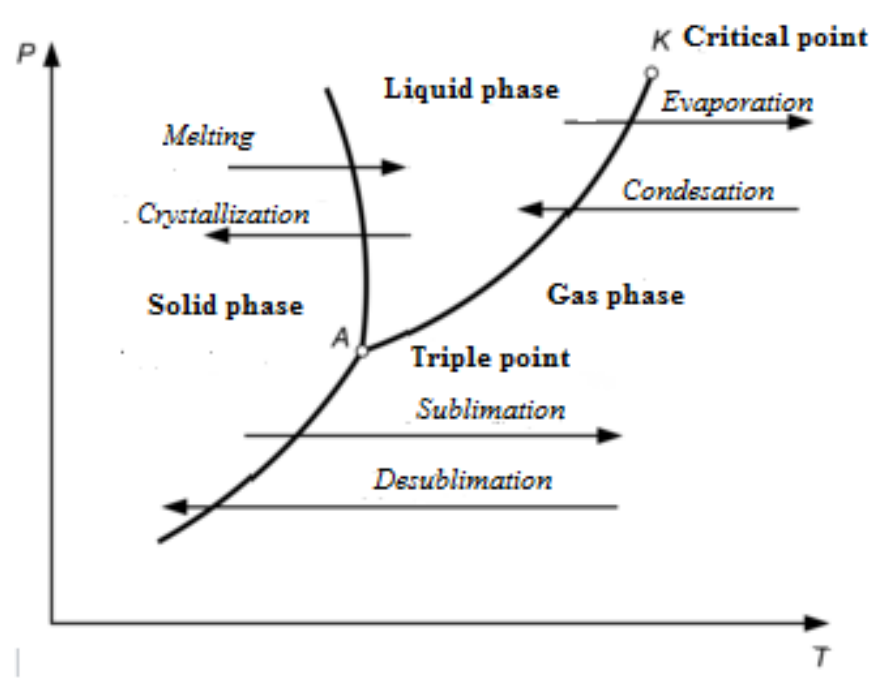

Fig. 6. First order phase transitions in the thermodynamic phase diagram [10]

Roughly speaking the elionic-induced sputtering may be represented as shock sublimation. But in this case we must use methods of modeling, which are connected with the intensity of the incident particles flow.

We begin our analysis from ion implantation. At implantation of large doses of ions are characteristic such effects: surface swelling, precipitation and cone formation [4]. In what follows, we will neglect these effects and assume that a homogeneous dispersed atomic mixture is formed. We also assume that atomic mixing is quite efficient, as a result of which the implanted atoms are evenly distributed in depth within the surface layer thickness $W$ (Fig. 7). With increasing concentration of implanted atoms $N_{A}$ a stream of atomized atoms $A$ increases and reaches the level of incident ion flux $J_{i}$ (type $A$ ). At the same time the steady state in which there is no further increase is established. According to this model, the steady state occurs after spraying a layer of thickness $\sim r W$, where $r$ is the coefficient of selective sputtering, and $W$ is the thickness of the implanted layer (in the order of magnitude equal to the mileage of ions). Under these assumptions, the shape of the concentration profile remains unchanged, and the concentration itself increases with increasing dose until steady state is reached. The condition of conservation of the number of atoms is written as follows [4]: 


$$
W \frac{d N_{A}}{d t}=J_{i}-J_{A}
$$

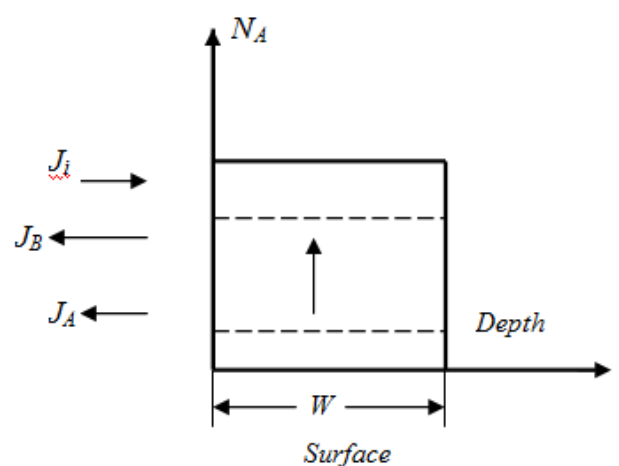

Fig.7. Illustration for calculating the concentration of implanted impurity

where $N_{A}$ - concentration of implanted atoms, $J_{i}$ - the flux of incident ions (element A), and $J_{A}$ - the flow of $A$ atoms atomizing from the target. In the steady state, the number of $A$ atoms in the material does not change, therefore:

$$
J_{A}=J_{i} \text {. }
$$

Enter the total spray ratio $S$ according to the formula:

$$
J_{A}+J_{B}=S J_{i} \text {, }
$$

where $J_{B}$ - the flow of B atoms atomizing from the target. Taking into account equality (2) we express $J_{B}$ through $J_{i}$ :

$$
J_{B}=(S-1) J_{i} .
$$

Now let's move away from the usual method of consideration and introduce the concept of selective sputtering. We assume that the scattering probabilities of $A$ and $B$ atoms are not the same:

$$
J_{B} / J_{A}=r\left(N_{B} / N_{A}\right),
$$

where $r$ - the ratio of the probability of sputtering of an $B$ atom located near the surface to the probability of sputtering of $A$ atom near the surface.

Then the stationary, or most possible, concentration will be determined by the expression [4]:

$$
N_{B} / N_{A}=r /(S-1)
$$

The ratio of concentrations is approximately inversely proportional to the sputtering coefficient $S$ and directly proportional to the selective sputtering coefficient $r$. For example, if $B$ atoms are atomized more likely than atoms $A(r>1)$, the concentration of $A$ atoms will be higher than in the absence of selective sputtering.

As an example of application of this model for calculation we will consider two cases of spraying by $A u$ ions with energy of $150 \mathrm{keV}$ [4]. Values $S$ and $W$ were determined by the method of Rutherford backscattering of ions. In both cases, the value $r$ was taken equal to one, although the results of experiments on the sputtering of the alloy $A u-C u$ indicate that for this alloy the value should be equal to 1.1, not 1.0.

Fig. 8 shows the dependence of the ratio of the concentration of implanted $A u$ atoms in the target on the thickness of the atomized layer divided by $W$. The calculated data are given by solid lines. 


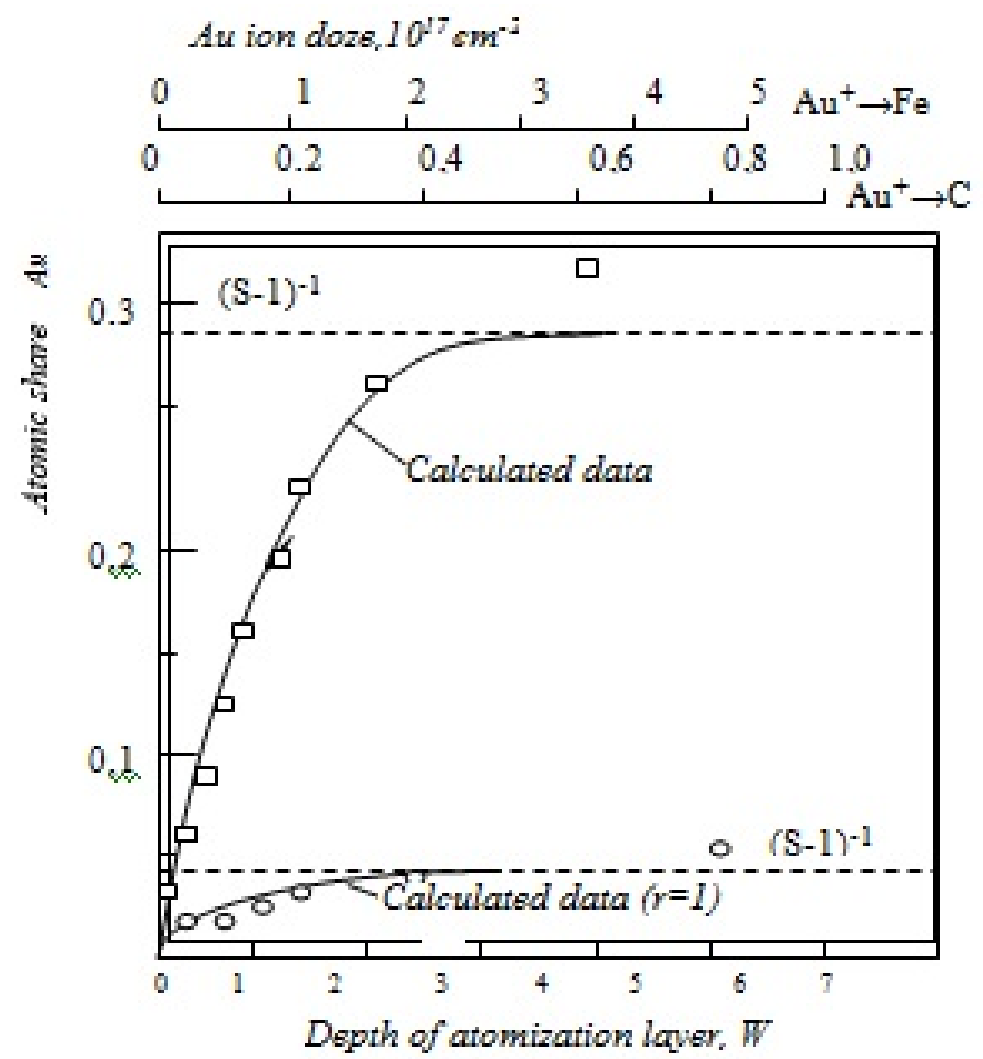

Fig. 8. Increasing the concentration of Au during the implantation of $\mathrm{Au}^{+}$ions with an energy of $150 \mathrm{keV}$ in Fe and $\mathrm{Cu}$. Squares: $\mathrm{Au}^{+} \rightarrow \mathrm{Fe}, S=4.4, W=49.3 \mathrm{~nm}$; circuit: $\mathrm{Au}^{+} \rightarrow \mathrm{Cu}, \mathrm{S}=20, \mathrm{~W}=41.4 \mathrm{~nm}$. The maximum concentration of $\mathrm{Au}$ achieved in $\mathrm{Cu}(\sim 5 \%)$ is much lower than in Fe. This is because $\mathrm{Cu}$ sprays more strongly than Fe. The curves are calculated on the basis of a simplified model (Fig. 7) taking into account the experimental values of $S$ and $W[4]$

The experimental points were obtained by the method of Rutherford backscattering ions [4]. The calculated results agree quite well with the experimental data. The calculations used experimentally determined values of two parameters: the total sputtering coefficient $S$ and the thickness of the implanted layer $W$. The difference in the maximum $A u$ impurity concentration, equal to 0.05 in the case $\mathrm{Au}^{+} \rightarrow \mathrm{Cu}$ and 0.3 in the case $\mathrm{Au} u^{+} \rightarrow \mathrm{Fe}$, reflects the difference in the spray coefficients of two materials $(\mathrm{Cu}$ and $\mathrm{Fe}$ ).

For more complex compounds, the sputtering ratio may be different for different elements, so you can get surfaces with variable stoichiometry. To explain such phenomena, more complex models need to be built [6-8].

In general, the sputtering coefficient depends on the energy of the incident particles, on their mass, on the target material, and on the angle of incidence of the incident particles. There is no unified theory. There are models that allow describing the main characteristics of the interaction for certain ratios between the masses of particles and their energies $[6,7]$.

Analogous models may be used for the electron-induced sputtering. Electron regimes of irradiation may be stationary and pulses. But in the time of electron and laser irradiation may be generated plasma and thermal processes $[2,3,7]$.

Basic difference between ion and electron irradiation and laser irradiation and laser irradiation is medium of irradiation: for ion and electron beams it is vacuum, for laser irradiation - air [4]. 
Other adverse effects include the damage to nearby structures and the area around the ablated area becomes wrinkled. As shown in Fig. 9 (b) [9], compared with the long-pulse laser, the ultrashort pulse laser has the advantages of very short pulse duration, high pulsepeak power, thermal effects and shock wave can be avoided, accurate targeting focused positioning and so on. Structures manufactured by femtosecond laser have extremely sharp edges compared to long pulses.
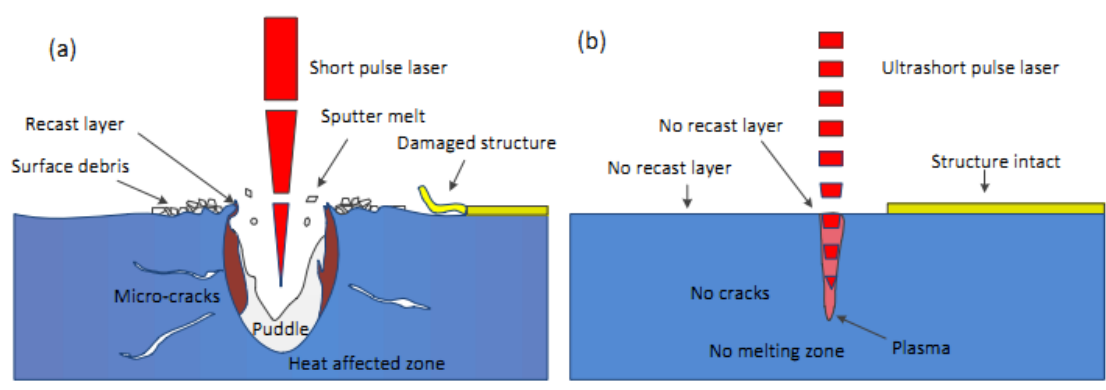

Fig. 9. Physical phenomena of irradiation by short laser pulse (a), ultrashort laser pulse (b) [9]

For explanation of laser-induced sputtering (sublimation) may be used cascade model in the regime of saturation of excitation [3]. We are demonstrating this model on $\mathrm{Si}$ and $\mathrm{Ge}$ examples.

Results of calculation of volume densities of energy, which are necessary for breakage of proper number of bonds in regime of saturation of excitation, are represented in Table 1 [3].

Table 1

Volume density of energy $I_{\mathrm{vi}}\left(10^{3} \mathrm{~J} / \mathrm{cm}^{3}\right)$, which is necessary for the breakage of proper number of chemical bonds in the regime of saturation of excitation in $\mathrm{Si}$ and $\mathrm{Ge}$ [3]

\begin{tabular}{|l|l|l|l|l|}
\hline & $I_{v 1}$ & $I_{v 2}$ & $I_{v 4}$ & $I_{v 5}$ \\
\hline $\mathrm{Si}$ & $12,8-14,4$ & $25,6-28,8$ & $51,2-57,6$ & $63-72$ \\
\hline $\mathrm{Ge}$ & $6,3-8,4$ & $12,6-16,8$ & $25,2-33,6$ & $31,5-42$ \\
\hline & & & & \\
\hline
\end{tabular}

It conceded that energies of all chemical bonds for elementary lattice are equivalent ( $S i$ and $G e$ are pure homeopolar semiconductors) [3, 4, 10]. For silicon energy of covalent bonds $\mathrm{Si}-\mathrm{Si}$ are equaled 1,2-1,8 eV; for germanium energy of covalent bonds $G e-G e$ are equaled 0,9 1,6 eV. Minimal values of these energies are corresponded of Pauling estimations. These values are corresponded the energy on one Coordination Number: according to radiation physics of status solid Seitz energy of creation one radiation defect in silicon is equal $12,7 \mathrm{eV}$ for diamond lattice $[3,4]$.

The values of molar volume, density of atoms, density of sublimation energy and value of siublimation energy on one atom for $\mathrm{Si}, \mathrm{Ge}$ and $\mathrm{Fe}$ are represented in Table 2 atoms and

Table 2

Thermodynamical characteristics, which are necessary for the sublimation silicon, germanium and steel $[10,11]$

\begin{tabular}{|c|c|c|c|c|}
\hline Material & $V_{\text {mol }}, \mathrm{cm}^{3}$ & $n_{i}, \mathrm{~cm}^{-3}$ & $E_{\text {subl }}, \mathrm{kJ} / \mathrm{cm}^{3}$ & $E_{\text {atomi }}, \mathrm{eV}$ \\
\hline $\mathrm{Si}$ & 12,18 & $5 \cdot 10^{22}$ & 36 & 4,50 \\
\hline $\mathrm{Ge}$ & 13,64 & $4 \cdot 10^{22}$ & 27 & 4,20 \\
\hline $\mathrm{Fe}$ & 7,14 & $8,4 \cdot 10^{22}$ & 56 & 4,16 \\
\hline
\end{tabular}


Comparative analysis of estimated data from Table 1 and Table 2 for silicon and germanium, show that for sublimation in thermodynamic approximation value energy per atom is equaled $0,35-0,45$ value of Seitz energy. For case of electron radiation (Fig. 2) this value is more-equal to Seitz energy. This difference is explained by the fact that during electron irradiation, an electron interacts with a nodal ion, and when interacting with a photon, the corresponding chemical bond is broken. Therefore, for laser-induced sublimation, the sputtering energy of sublimation of surface ions should be less than half the Seitz energy.

In general, these processes can be considered as kinetic phase transitions of the first order, and thus it can be considered as an extension of Haken's concept of the equivalence of thermodynamic phase transitions of the second order and kinetic nonequilibrium phenomena (for example, nonlinear optical phenomena) [12] to phase transitions of the first order (irreversible phenomena).

Thus, when calculating the modes of laser-induced sublimation for steel, we should use the data in Table 2. It should be noted that when focusing the laser radiation, the effect of diffraction stratification of the incident radiation should be taken into account, which, depending on the radiation intensity, can affect transverse dimensions from 10 to $100 \mu \mathrm{m}$ depending on the wavelength of the laser radiation. Thus, for technological purposes, it is advisable to choose wider radiation beams. Therefore, it is desirable to carry out irradiation with collimated parallel, rather than focused, beams.

\section{Conclusions}

1. Comparative analysis of basic four methods (ion, neutron, electron and laser induced) receiving of sublimation (sputtering) of matter is represented. analyzed.

2. The experimental data of ion, electron, neutron and laser-induced sputtering are

3. Physical-chemical methods of modeling these processes and phenomena are selected and discussed.

4. Main peculiarities of laser-induced sublimation as more soft process is described and analyzed.

5. The relationship and difference between the thermodynamic theory of sublimation and kinetic theories of sputtering are shown.

\section{Список використаної літератури}

1. Риссел Х., Руге И. Ионная имплантация. М. : Наука, 1983. 360 с.

2. Технологические процессы и системы в микроэлектронике: плазменные, электронно-ионно-лучевые, ультразвуковые. Под ред. академика А. П. Достанко. Минск : Бестпринт, 2009. 204 с.

3. Trokhimchuck P. P. Relaxed Optics: Modeling and Discussions. Saarbrukken : Lambert Academic Publishing, 2020. 249 p.

4. Трохимчук П. П. Радіаційна фізика твердого тіла. Луцьк : Вежа, 2007. 394 с.

5. Чернов А. А. Физика кристаллизации. Новое в жизни, науке, технике. Серия «Физика», №5. Москва : Знание, 1983. 64 с.

6. Sputtering by Particle Bombardment I. Physical Sputtering of Single-Element Solids. Ed. Behrisch R. Berlin: Springer Verlag, 1981. 328 p.

7. Sputtering by Particle Bombardment II. Sputtering of Alloys and Compounds, Electron and Neutron Sputtering, Surface Topography. Ed. Behrisch R. Berlin : Springer Verlag, 1983. $484 \mathrm{p}$.

8. Sputtering by Particle Bombardment III. Experiments and Computer Calculations from Threshold to MeV Energies. Eds. Behrisch R., Eckstein W. Berlin: Springer Verlag, $1991.320 \mathrm{p}$. 
9. Dupliak I., Li F., Feng F. Micro-hole drilling of stainless steel using short pulse laser. Actual Problems of Fundamental Science: Proceedings Third International Conference dedicated to the memory of Anatoliy V. Svidzinskyi ( Lake "Svityaz", I - 5 June, 2019). Lutsk : Vezha-Print, 2019. P. 42-44.

10. Мешков Ю. Я. Концепция критической энергии при разрушении твердых тел. Успехи физики металлов. 2001. Том 2. С. 7-50.

11. Whitten K. W., Gailey K. D., Davis R. E. General chemistry with qualitative analysis. Rochester: Saunders College Publishing, 1994. 475 p.

12. Haken H. Synergetics. An Introduction. Nonequilibrium phase transitions and SelfOrganization in Physics, Chemistry and Biology. Berlin a.o.: Springer-Verlag, 1977. 325 p.

\section{References}

1. Rissel, H., \& Ruge, I. (1983). Ionnaya implantatsiya. M.: Nauka.

2. Tekhnologicheskiye protsessy i sistemy v mikroelektronike: plazmennyye, elektronnoionno-luchevyye, ul'trazvukovyye. Pod red. akademika A. P. Dostanko. (2009). Minsk: Bestprint.

3. Trokhimchuck, P. P. (2020). Relaxed Optics: Modeling and Discussions. Saarbrukken: Lambert Academic Publishing.

4. Trokhumchuck, P. P. (2007). Radiatsiyna fizyka tverdoho tila. Luts'k : Vezha.

5. Chernov, A. A. (1983). Fizika kristallizatsii. Novoye v zhizni, nauke, tekhnike. Seriya «Fizika», №5. Moskva : Znaniye.

6. Sputtering by Particle Bombardment I. Physical Sputtering of Single-Element Solids. Ed. Behrisch R. (1981). Berlin: Springer Verlag.

7. Sputtering by Particle Bombardment II. Sputtering of Alloys and Compounds, Electron and Neutron Sputtering, Surface Topography. Ed. Behrisch R. (1983). Berlin: Springer Verlag.

8. Sputtering by Particle Bombardment III. Experiments and Computer Calculations from Threshold to MeV Energies. Eds. Behrisch R., Eckstein W. (1991). Berlin: Springer Verlag.

9. Dupliak, I., Li, F., \& Feng, F. (2019). Micro-hole drilling of stainless steel using short pulse laser. Actual Problems of Fundamental Science: Proceedings Third International Conference dedicated to the memory of Anatoliy V. Svidzinskyi ( Lake "Svityaz", I-5 June, 2019). Lutsk: Vezha-Print. P. 42-44.

10. Meshkov, Yu. Ya. (2001). Kontseptsiya kriticheskoy energii pri razrushenii tverdykh tel. Uspekhi fiziki metallov. 2, 7-50.

11. Whitten, K. W., Gailey, K. D., \& Davis, R. E. (1994). General chemistry with qualitative analysis. Rochester: Saunders College Publishing.

12. Haken, H. (1977). Synergetics. An Introduction. Nonequilibrium phase transitions and Self-Organization in Physics, Chemistry and Biology. Berlin a.o.: Springer-Verlag.

Трохимчук Петро Павлович-к.ф.-м.н., доцент кафедри теоретичної та комп'ютерної фізики імені $A$. В. Свідзинського Волинського національного університету імені Лесі Українки, e-mail: trope1650@gmail.com, ORCID: 0000-00032737-0506. 